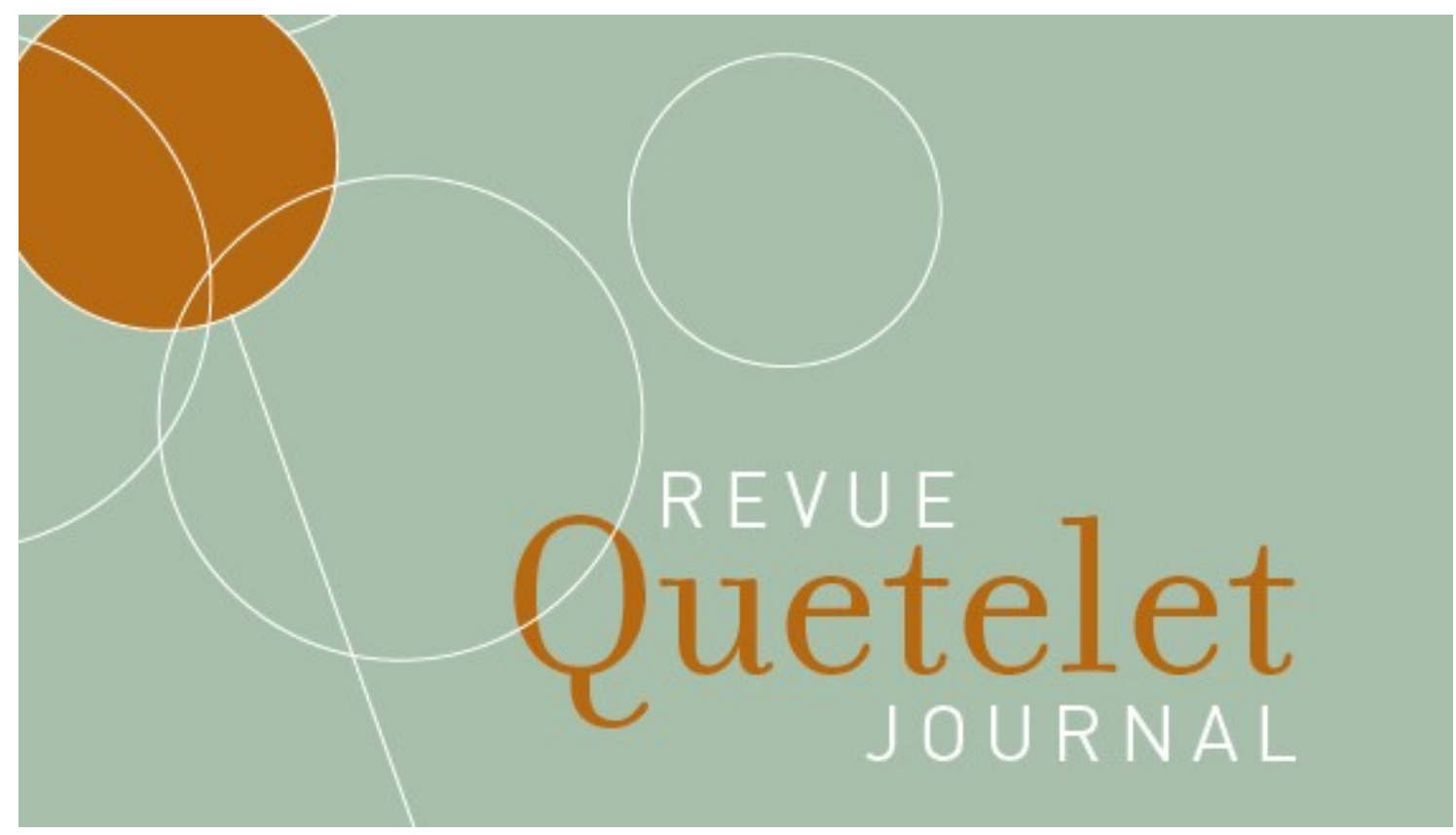

Vol. 4, n 1, avril 2016, pp. 73-99

http://www.uclouvain.be/437999.html

DOI : 10.14428/rqj2016.04.01.04

\title{
Voluntary, involuntary and temporary childlessness in the United States
}

Dudley L. Poston Jr, Cristina Elizabeth Cruz

This work is licensed under a Creative Commons Attribution-NonCommercial 4.0 International License. You can share, adapt the material for non-commercial purposes provided that you give appropriate credit and indicate if changes were made. For details see https://creativecommons.org/licenses/by-nc/4.0/

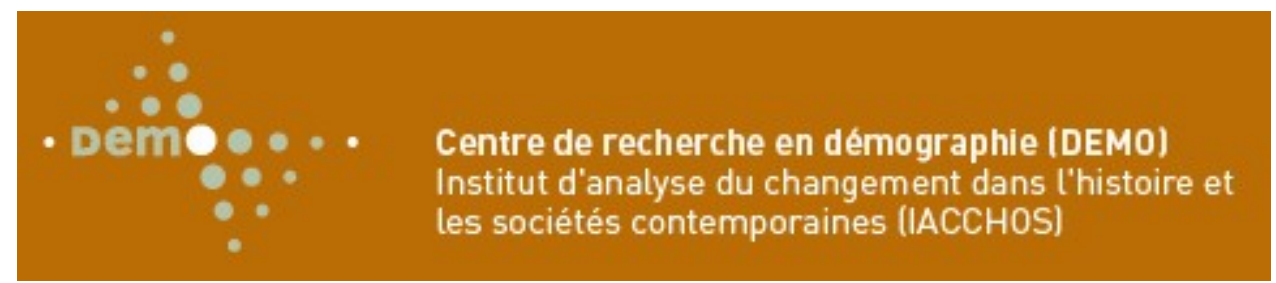




\title{
Voluntary, involuntary and temporary childlessness in the United States
}

\author{
DUdLEY L. POSTON, JR. ${ }^{1}$ \\ CRistina Elizabeth CRuz ${ }^{1}$
}

\section{Résumé}

Cet article étudie la prévalence, les profils ainsi que les modèles d'infécondité aux Etats-Unis. Après une revue de littérature, nous analysons les taux d'infécondité parmi les populations de femmes blanches, noires et hispaniques. Nous en examinons les tendances sur un siècle, de 1910 à 2010. Par la suite, nous utilisons les données du National Survey for Family Growth de 2006-2010 pour déterminer la part d'infécondité volontaire, involontaire et temporaire parmi ces trois groupes de femmes. Une fois cette catégorisation effectuée, nous estimons un modèle de régression logistique multinomial afin de prédire, pour chaque femme, la probabilité d'appartenir à un groupe infécond plutôt qu'à un autre ou encore au groupe des femmes fécondes. Pour conclure, nous discutons certaines implications de nos analyses et prédisons les niveaux et tendances futurs de l'infécondité.

\section{Mots-clés}

Infécondité volontaire, infécondité involontaire, infécondité temporaire, régressions logistiques multinomiales, Hispaniques, Blancs, Noirs.

\begin{abstract}
This article focuses on the prevalence, patterns and models of childlessness in the United States. We first review the childlessness literature. We then analyze childlessness rates among White, Black and Hispanic women. We examine childlessness trends for the 100-year period from 1910 to 2010 for the above three groups. Next we use data from the 2006-10 National Survey of Family Growth to examine the degree of voluntary, involuntary, and temporary childlessness among these groups of women. Having categorized the childless women according to their type of childlessness, we then estimate multinomial logistic regression equations predicting the likelihood of a woman being in each of the childlessness groups, versus being in the group of women having children. We conclude by drawing out some of the implications of our analyses and suggest the future prevalence and trends in childlessness.
\end{abstract}

1. Department of Sociology, Texas A\&M University, College Station, Texas 77843. 


\section{Keywords}

Voluntary childlessness, involuntary childlessness, temporary childlessness, multinomial logistic models, Hispanics, Whites, Blacks

\section{Introduction}

In this article we analyze childlessness rates among White, Black and Hispanic women in the U.S. We first review the childlessness literature. Then we examine childlessness trends for the 100 year period from 1910 to 2010 for the above three groups. Next we use data from the 2006-10 National Survey of Family Growth to examine the degree of voluntary, involuntary, and temporary childlessness among these three groups of women. Having categorized them according to their type of childlessness, we then estimate multinomial logistic regression equations predicting the likelihood of a woman being in each of the childlessness groups, versus being in the group of women having children.

Recent years have seen dramatic increases in the percentages of evermarried women in the United States who are childless. In the 1970s almost one-half of White women who were born in the 1950s were childless at age 25. Rindfuss and his colleagues expected that as many as $20 \%$ of these White women would still be childless at the end of their childbearing years (Rindfuss et al., 1988). More recently, data from the June 2008 Current Population Survey indicate that $53 \%$ of White women in the age group 25-29, and 30\% of women aged 25-29, are childless (the corresponding percentages for Black and Hispanic women are 33\% and 24\% for Blacks, and 31\% and 18\% for Hispanics) (see U.S. Bureau of the Census, 2010). As many as 20 to $25 \%$ of these White women are likely to be childless at the end of their childbearing years, with somewhat smaller percentages of permanent childlessness among the Black and Hispanic women (Morgan et al., 1992; see also Rindfuss et al., 1988). The percentages are a little lower for ever-married women, as we will show below. But nevertheless, the striking finding is the increasing levels of childlessness in recent decades.

\section{Review of literature}

Childlessness is, and has been since the 1970s, a much more prevalent phenomenon than it was in the 1950s when childlessness was low and 
little of it, if any, was voluntary (Poston et al., 1983). Indeed demographers noted that in the 1950s, «voluntary childlessness... (was) nearly extinct» (Whelpton et al., 1966, p. 163). Until the early 1970s, the norms relating to marriage and procreation were pervasive and pronatalist, much more so than they are today. The literature written thirty to forty years ago indicated that childlessness was neither supported nor encouraged by the society's normative and value structure (Poston, 1974). The childed state was heavily valued in its own right (Griffith, 1973), and those remaining without children often experienced severe negative sanctions (Veevers, 1973; Blake, 1974; Dykstra, 2009).

We have mentioned the low prevalence of childlessness in the 1950s and 1960s in the U.S. However, it would be a mistake to refer to the increase in childlessness since the 1970 s as reflecting a so-called secular phenomenon and not as representing the more distant past. For instance, using data from the 1900 census and later censuses, Morgan (1991) has shown that levels of childlessness in the nineteenth century were much higher than those reported for the 1950s and early 1960s (see also Poston et al., 1977; Dykstra, 2009). Nonetheless, little attention was given to childless women in the United States prior to the 1970s, and the research that was being conducted at that time focused mostly on involuntarily childlessness (Poston et al., 1983). These early studies assumed that childlessness was caused primarily by sterility or subfecundity and not by voluntary decisions to stay childless (Poston, 1976).

Interestingly, the percentages of married women aged 15-44 who were childless in the United States have fluctuated over time. In the 1970s when childlessness was increasing, researchers believed that most of the increase was due especially to white women choosing to be childless (Poston et al., 1977). More recent studies have supported this idea of increased childlessness especially at the older ages. Abma and Martinez (2006) focused on childlessness among older women (ages 35-44) and reported that voluntary childlessness rose from 5\% in 1982 to $8 \%$ in 1988, and was maintained until 1995 at $9 \%$ before falling slightly to $7 \%$ in 2002. They also reported that women who were voluntarily childless tended to have the highest incomes, work experiences and lowest religiosity. Also, Downs (2003) reported that in 2002, 18\% of older women (ages 40 to 44 ) were childless, compared to $10 \%$ of the women in the same age group in 1976. However, Toulemon's (1996) analysis of vital registration and census data from France, and the research of Debest, Mazuy and colleagues (2014) using survey and attitudinal data, also from France, report rather low percentages of women and men in the later 
childbearing ages being or wishing to be childless. Actually, the childlessness percentage data for France are not that much lower than the data for the U.S. and most of the European countries (Rowland, 2007, see below). It is the attitudinal and preference data that are low, not the data reflecting actual behavior. This is consistent with the research of Veevers (1973) that more than half of the childless women she interviewed reported that they had not intended to remain childless, but kept postponing indefinitely the decision to have a birth.

Baudin, de la Croix and Gobbi (2015) have reported a U shaped association between education and childlessness, with women with low levels of education having high rates, women with middle levels having low rates, and women with high levels having high rates. This U-shaped relationship is largely attributed to the fact that women with low levels of education tend mainly to be involuntarily childless, and women with high levels tend to be voluntarily childless, a point also made by McFalls (1979a) and Poston and Trent (1982), and one which we will subject later in this paper to empirical test.

Research on women of all fecund ages has yielded fairly similar results. In 1997, Abma and her colleagues reported that $9 \%$ of all women in the U.S. between the ages of 15 and 44 in 1995 were childless and expected to remain childless, of which $7 \%$ were voluntarily childless. They showed a slight increase in voluntary childlessness from $5 \%$ in 1982 to $6 \%$ in 1988 (Abma et al., 1997). Similarly, Abma and Peterson in 1995 reported that in the 1970 s, $12 \%$ of all the women who were childless were childless by choice, while in 1990 the percentage had risen to 25\% (Park, 2005). Therefore, the continued study of voluntary childlessness is certainly warranted.

The increases in voluntary childlessness are likely due in part to changes in gender norms, just as researchers hypothesized in the 1960s. Koropeckyj-Cox and Pendell (2007) examined data from the National Surveys of Families and Households for 1987-1988 and 1992-1994 and discovered that more than $86 \%$ of the respondents were neutral or agreed that childless individuals could have fulfilling lives. Their research showed that more positive attitudes towards childlessness were found among females who were college educated and/or childless; the less positive attitudes were found among older, less educated males who were religiously conservative. This suggests that attitudes and norms towards childlessness are becoming more positive overall, which may explain in part the increased levels of childlessness in the U.S.

Furthermore, it is very important to distinguish between voluntary childlessness and involuntary childlessness and the mediating stage that is 
termed temporary childlessness. Involuntary childlessness usually refers to the biological inability of a person to reproduce, or to issues of subfecundity, i.e., "the diminished capacity to reproduce» (McFalls, 1979a). Causes of subfecundity include «genetic factors, psychopathology, disease, nutritional deficiencies and environmental factors»; among the genetic factors are abnormalities in chromosomes and metabolism, anemia, and red blood cell incompatibility between partners (Poston et al., 1983, pp. 441-442). Environmental factors include radiation and toxic chemical exposure and occupational hazards (McFalls 1979a, 1979b). In the more developed countries as opposed to the developing countries, additional issues are likely to contribute to subfecundity such as drug abuse, psychoses and stress (Poston et al., 1983).

Most of the literature on childlessness focuses on analyses of U.S. women. Rowland (2007) has extended the geographic coverage in his examination of changes in the rates of childlessness among women in Europe, Australia, the U.S. and Japan. His extensive study considered the childlessness experiences of women in birth cohorts from 1890 to 1954 in $23 \mathrm{Eu}-$ ropean countries and in Canada, the U.S., Israel, Australia and New Zealand. He found truly remarkable similarities in the childlessness data for women in most of the countries, namely, «a pronounced decline in the proportions childless for cohorts born between 1900 and 1940, and an increase in childlessness among more recent birth cohorts» (Rowland, 2007, p. 1'317). Also, Dykstra (2009) has studied childlessness among the older population, i.e., of age 45 , focusing in particular on childlessness among the married and never-married, as well as «childlessness» to parents whose children have died (also see Rowland, 1998a, 1998b).

Voluntary childlessness on the other hand, refers to a woman's decision to have no children at all. There are various factors associated with a woman's likelihood of being voluntarily childless. Often it is not a choice decided on at one point in time but a collection of decisions over time postponing motherhood that eventually culminates in childlessness (Poston et al., 1983). It is also important to acknowledge that a woman's status as being either voluntarily childless or involuntarily childless is not always easily distinguishable (Park, 2005). Although some women may believe they know where they belong on the childlessness spectrum, others place themselves somewhere in between, or feel their classification shifts with the passage of time (Letherby, 2002). The childlessness literature has distinguished between women who are early articulators, i.e., those who decide to be childless early on in their life, often before marriage, and postponers, i.e., women who become childless as a result of various decisions to delay motherhood (Houseknecht, 1987; Veevers, 1973). For the 
purpose of this article, women who are childless at the time of the NSFG interview but who plan on having children in the future will be considered temporarily childless (Poston et al., 1983).

In any event, childlessness is certainly an important and relevant fertility response among women in the U.S. today. We need to know more about its current levels, its dynamics, and the kinds of characteristics that are likely and not likely to be associated with women who are childless. We now examine 100 years of census data to examine childlessness trends over time.

\section{Trends in childlessness}

Since 1940, the U.S. Bureau of the Census has published data on the number of children ever born to women in the United States. The Bureau typically obtains these data in the decennial censuses and the Current Population Surveys. When the Bureau published data from the 1940 census, it also provided fertility data from the 1910 census (U.S. Bureau of the Census, 1943 , pp.1-6). We are thus able to assemble percentage rates of childlessness for ever-married U.S. women for fourteen time periods covering the 100 years from 1910 to 2010 . These data are shown in Table 1.

Table 1 presents schedules of age-specific rates of childlessness for White, Black and Hispanic ever-married women ${ }^{2}$. Previous analyses have mainly focused either only on White women, or on women without regard to their race/ethnicity. We hold it is important to separate the women according to their race and ethnic group because, as we show here, the rates for all three racial/ethnic groups of ever-married women vary considerably within any one time period, as well as over time within any one age group; this is especially true for White women. To illustrate, as few as $5 \%$ of ever-married White women 35-39 years old were childless in 1975; but by 2010 more than $14 \%$ of women in this age group had no children, whereas back in 1950 the corresponding figure was $18 \%$.

2. The Census Bureau uses two questions to identify one's race and Hispanic origin; one question asks the person to identify his/her race (e.g., White, Black, Asian, other); the other question asks if the person is of Hispanic origin (yes/no). In this article, when we refer to Hispanic women, we mean Hispanic women of all races. When we refer to White women we mean women who designate their race as White, and they may be Hispanic or NonHispanic, and similarly for Black women. In several places we have data for Whites and for Hispanic origin, so we are able to refer to NonHispanic White women (and in some cases to NonHispanic Black women). If we are referring to NonHispanic White (or Black) women, we will use the adjective NonHispanic or $\mathrm{NH}$. 
TABLE 1 Percent of ever-married women who are childless, by age, and race/ethnicity: Selected years between 1910 and 2010, United States

Age group, White woman

\begin{tabular}{|l|r|r|r|r|r|}
\hline $2010^{1}$ & $20-24$ & $25-29$ & $30-34$ & $35-39$ & $40-44$ \\
\hline $2005^{1}$ & 38.0 & 30.7 & 18.6 & 13.1 & 13.3 \\
\hline $2000^{1}$ & 36.2 & 30.3 & 18.0 & 13.6 & 14.4 \\
\hline $1995^{2}$ & 37.5 & 29.7 & 19.3 & 13.3 & 13.6 \\
\hline $1990^{3}$ & 40.3 & 30.6 & 17.4 & 12.1 & 11.5 \\
\hline $1985^{4}$ & 41.3 & 30.0 & 19.5 & 12.3 & 8.4 \\
\hline $1980^{5}$ & 42.3 & 26.6 & 14.1 & 8.1 & 6.4 \\
\hline $1975^{6}$ & 44.7 & 21.6 & 8.9 & 5.2 & 6.5 \\
\hline $1970^{6}$ & 37.7 & 16.1 & 8.1 & 7.0 & 8.1 \\
\hline $1965^{9}$ & 28.7 & 11.8 & 7.0 & 8.1 & 10.2 \\
\hline $1960^{8}$ & 25.0 & 12.3 & 9.7 & 10.2 & 13.0 \\
\hline $1950^{11}$ & 34.0 & 20.1 & 15.8 & 17.5 & 18.9 \\
\hline $1940^{12}$ & 36.9 & 27.2 & 20.6 & 17.1 & 15.2 \\
\hline $1910^{13}$ & 24.2 & 16.8 & 13.4 & 11.5 & 10.4 \\
\hline
\end{tabular}

Non-Hispanic White woman

\begin{tabular}{|l|c|c|c|c|c|}
\hline & $20-24$ & $25-29$ & $30-34$ & $35-39$ & $40-44$ \\
\hline $2010^{1}$ & 43.6 & 35.1 & 19.8 & 14.2 & 14.3 \\
\hline $2005^{1}$ & 43.2 & 34.1 & 19.7 & 14.3 & 15.1 \\
\hline $2000^{1}$ & 41.1 & 34.0 & 20.0 & 13.9 & 14.3 \\
\hline
\end{tabular}

Black woman

\begin{tabular}{|l|r|r|r|r|r|}
\hline & $20-24$ & $25-29$ & $30-34$ & $35-39$ & $40-44$ \\
\hline $2010^{1}$ & 30.2 & 22.8 & 20.4 & 12.5 & 11.2 \\
\hline $2005^{1}$ & 24.2 & 22.7 & 14.2 & 11.5 & 11.3 \\
\hline $1900^{1}$ & 20.6 & 21.1 & 14.2 & 13.2 & 12.5 \\
\hline $1990^{3}$ & 29.4 & 16.4 & 13.9 & 10.7 & 11.7 \\
\hline $1985^{4}$ & 26.2 & 14.7 & 11.7 & 8.8 & 9.8 \\
\hline $1980^{5}$ & 43.5 & 16.5 & 8.4 & 6.9 & 6.1 \\
\hline $1975^{6}$ & 20.2 & 15.9 & 8.3 & 6.4 & 11.4 \\
\hline $1970^{6}$ & 20.8 & 12.3 & 9.1 & 9.8 & 13.0 \\
\hline $1965^{9}$ & 22.4 & 10.5 & 8.5 & 13.3 & 17.8 \\
\hline $1960^{8}$ & 17.4 & 14.5 & 15.5 & 19.3 & 23.7 \\
\hline $1950^{11}$ & 28.6 & 29.6 & 30.2 & 31.9 & 29.6 \\
\hline $1940^{12}$ & 34.9 & 31.4 & 28.5 & 26.3 & 23.4 \\
\hline $1910^{13}$ & 24.1 & 19.5 & 16.4 & 13.2 & 10.4 \\
\hline
\end{tabular}




\begin{tabular}{|l|c|c|r|r|r|}
\multicolumn{3}{l}{ Hispanic woman } \\
\hline $2010^{1}$ & $20-24$ & $25-29$ & $30-34$ & $35-39$ & $40-44$ \\
\hline $2005^{1}$ & 24.1 & 14.1 & 14.3 & 8.9 & 8.2 \\
\hline $2000^{1}$ & 21.7 & 14.8 & 11.7 & 10.8 & 9.3 \\
\hline $1995^{2}$ & 25.5 & 16.1 & 14.7 & 9.5 & 7.6 \\
\hline $1990^{3}$ & 26.2 & 19.4 & 11.4 & 4.3 & 6.6 \\
\hline $1985^{4}$ & 28.8 & 17.3 & 13.1 & 5.7 & 5.0 \\
\hline $1980^{5}$ & 30.0 & 15.1 & 7.0 & 8.4 & 6.9 \\
\hline $1975^{6}$ & 31.2 & 15.6 & 6.3 & 2.6 & 4.1 \\
\hline $1970^{7}$ & 24.3 & 11.3 & 7.0 & 6.0 & 7.8 \\
\hline $1960^{10}$ & 15.8 & 7.9 & 6.5 & 7.0 & 8.8 \\
\hline $1950^{11}$ & 21.0 & 10.8 & 10.7 & 12.0 & 11.5 \\
\hline
\end{tabular}

Data sources: ${ }^{1}$ U.S. Bureau of the Census, $2011 ;{ }^{2}$ U.S. Bureau of the Census, 1997, Table 1; ${ }^{3}$ U.S. Bureau of the Census, 1991, Table 1; ${ }^{4}$ U.S. Bureau of the Census, 1986, Table 1; ${ }^{5}$ U.S. Bureau of the Census, 1982, Table 12; ${ }^{6}$ U.S. Bureau of the Census, 1976 , Table 17; ${ }^{7}$ U.S. Bureau of the Census, 1973, Table 13; ${ }^{8}$ U.S. Bureau of the Census, 1964, Table 4; ${ }^{9}$ U.S. Bureau of the Census, 1969, Table 1; ${ }^{10}$ U.S. Bureau of the Census, 1973, Table 11; ${ }^{11}$ U.S. Bureau of the Census, 1955, Table 2; ${ }^{12}$ U.S. Bureau of the Census, 1943, Table 1; ${ }^{13}$ U.S. Bureau of the Census, 1943, Table 2.

The percentage data in Table 1 for the periods of 1960 to 2010 enable us to examine changes in childlessness for eleven open cohorts ${ }^{3}$ of evermarried White and Black women, for ten open cohorts of ever-married Hispanic women, and for three open cohorts of ever-married NonHispanic White (NH White) women, with each cohort identified by the year in which its members were 20-24 years old. For White and Black women these are the 1960, 1965, 1970, 1975, 1980, 1985, 1990, 1995, 2000, 2005 and 2010 cohorts. For Hispanic women, data are available for the last nine cohorts. And for NH White women, data are only available for the last three cohorts. The 1960, 1965, 1970, 1975, 1980, 1985, and 1990 cohorts have completed their childbearing years, that is, they surpassed age 45 before the year of 2010 .

3. These cohorts are open cohorts. Women become members as they marry. Once married, they retain membership, irrespective of subsequent changes in marital status. For examples from the cohort literature in demography, see Price $(1968 ; 1974)$. In a few instances, the rate of childlessness at a later age, e.g., 40-44, may be slightly higher than its rate at an earlier age, e.g., 35-39; this phenomenon is due to both sampling and cohort attrition. 
We first consider the childlessness rates for the cohorts of White women. The 1960 cohort began its childbearing years (which, for the purposes of our analysis, is at age $20-24^{4}$ ) with a childlessness rate of $25 \%$; by the time it was in its last years of childbearing (at age 40-44 in 1980), $6.4 \%$ of its members were childless (here see the childlessness percentage for the 40-44 group in 1980). The 1965, 1970 and 1975 cohorts have also completed their childbearing years. At each age, the childlessness rates of the 1965 cohort are higher than those of the 1960 cohort, at each age the rates of the 1970 cohort are higher than the rates of the 1960 and 1965 cohorts, and at each age the rates of the 1975 cohort are higher than those of the 1960, 1965 and 1970 cohorts. Thus, each cohort is characterized by higher age-specific rates of childlessness that the cohort preceding it.

The next three cohorts, i.e., those of 1980, 1985, and 1990 have also completed their childbearing years, but all three have started with age-specific rates at age 20-24 that are a little lower than the childlessness rate at age 20-24 of the 1975 cohort. However, all three have completed rates of childlessness, i.e., at age $40-44$, that are higher than the rate of the 1975 cohort. The last cohort completing its childbearing years, the 1990 cohort, has a completed rate of childlessness one percentage point less than its preceding cohort. But even still, at a level of $13.3 \%$, a completed rate of childlessness this high has not been achieved since the cohort of 1930 with a completed percentage rate of 18.9 .

The last four cohorts, those of 1995, 2000, 2005 and 2010 have not yet completed their childbearing years, so we do not yet have completed rates of childlessness for them. But their age-specific percentage rates at the earlier ages all suggest the strong likelihood that their completed rates of childlessness will be in the 13 to $14 \%$ range.

We only have data for three cohorts of NonHispanic White women, i.e., 2000, 2005 and 2010. None of them have completed their childbearing years, but their age-specific rates for the younger ages are all one or two percentage points higher than for White women. Thus we anticipate that the completed rates for $\mathrm{NH}$ White women will likely be between 14 and $15 \%$.

There is not as much regularity in the cohort-specific childlessness rates for Black women. The 1960 cohort has the lowest age-specific childlessness rates of all the cohorts, and a completed childlessness rate of 10.6

4. Since proportionally few women in the U.S. marry before age 20, and since most childbearing is completed by age 44, we restrict the ages of the cohorts to 20 to 44 , as against the conventional (and larger) age interval of 15 to 49. 
percent. The 1980 cohort has the highest rate of completed childlessness of all the cohorts, at $12.5 \%$. On average all the Black cohorts after 1995 have, and likely will have, completed rates of 11 to $12 \%$, just a few points less than the White cohorts.

The overall rates and the completed rates of childlessness for Hispanic women are for the most part lower than those for the White and Black cohorts. Completed rates range, and are likely to continue to range, from between 8 and $10 \%$.

This discussion of childlessness trends for ever-married White, $\mathrm{NH}$ White, Black and Hispanic women provides a broad perspective for our consideration of the childlessness phenomenon. For the most part, our analyses show higher levels of age-specific rates of childlessness for the more recent cohorts compared to the earlier cohorts, a finding also of Rowland (2007) in his international study of childlessness. On average, between 13 and 14\% of White ever-married women complete their childbearing years with no children ever-born; the rates of $\mathrm{NH}$ White women are one or two points higher, and one or two points lower for Black women. Hispanic women have completed rates that are one to two points lower than Blacks.

We turn next to a cross-sectional analysis of childlessness in which we distinguish several types of childlessness among women who have no children. Data from the Current Population Survey as reported in Table 1 (above) do not allow us to distinguish among childless women who are voluntarily, involuntarily, and temporarily childless. But these are very important distinctions because, among other considerations, some of their causes are not likely the same.

\section{Categories of childlessness}

There are several methods for separating childless women into various categories (Poston et al., 1983; Wilkie, 1984; Houseknecht, 1987; among others). The two main methods are a cognitive approach and a behavioral approach. We first discuss the two approaches. We then implement the behavioral approach to separate women according to the various categories of childlessness using data for women sampled in the 2006-10 National Survey of Family Growth.

The cognitive method relies on the women's knowledge of their ability to conceive children. The behavioral method is based on the contraceptive behavior of the women. We now discuss these two separation strategies. 
In endeavoring to separate various categories of childlessness, we begin with a population of childless women who were not pregnant at the time of the NSFG interview. We omit childless women who were pregnant at the time of interview because their accurate categorization is ambiguous, if not impossible. Working thus with childless women who were not pregnant, we then ascertain their fertility intentions. Those who had no children at the time of the NSFG interview but intended to have children in the future are set aside as temporarily childless.

It is at this point that the distinction emerges between the cognitive and behavioral approaches. The cognitive method involves inquiring about the woman's knowledge of her fecundity. If a woman with no children who was not pregnant at interview time knew that she was capable of having children, yet planned to have none in the future, we categorize her as voluntarily childless. On the other hand, if a woman with no children who was not pregnant knew that she was unable to have children in the future, we categorize her as involuntarily childless, as long as her inability to conceive is not the result of a sterilizing operation performed for contraceptive reasons.

Alternately, the behavioral approach involves examining the contraceptive behavior of women with no children who were not pregnant at the time of the interview. If a childless woman who did not intend to have children was contracepting, or she was not contracepting but she or her male partner had been contraceptively sterilized, i.e., she had a tubal ligation or he had a vasectomy, we then assume she was choosing of her own volition not to have children in the future. But if she was not contracepting, and she or her partner had not been contraceptively sterilized, we conclude that she is involuntarily childless. This involuntarily childless group includes noncontracepting woman with no sterilizing operation and noncontracepting women with a sterilizing operation that was not performed for contraceptive reasons, e.g., a hysterectomy.

The categories of childlessness produced by both methods are not perfect and have some reliability and validity problems. Some of the voluntarily childless may be biologically incapable of having children, but are not aware of their sterility or subfecundity. However, defining themselves as voluntary, warrants to some extent classifying them as voluntary. For as W. I. Thomas observed many years ago, if persons «define situations as real, they are real in their consequences» (cited in Merton [1957, p. 421]).

In a similar vein, many of the involuntarily childless may not define as problematic their presumed biological inability to produce children. They could well have intended in the first place to have no children, and then either discovered they were biologically incapable of having children or 
became sterile through an operation not performed for contraceptive reasons. Thus, although they are not now able to have children, they may not have been inclined to have children anyway.

The temporarily childless are even more enigmatic. They will eventually join the ranks of the voluntarily childless, the involuntarily childless, or the childed. At this point, no one knows for certain which group they will join, irrespective of their childbearing intentions (Veevers, 1973; Poston et al., 1983).

These are only a few of the problems that are inherent in any attempt to identify various categories of childlessness with data from fertility surveys. Veevers noted many years ago that «in order to place individuals in the appropriate (childlessness) category, it is necessary to know details concerning not only their health, but also their innermost motivations and aspirations. Such data can be gleaned only in intensive personal interviews and are not readily available from representative samples of large populations» (Veevers, 1972).

Despite the problems discussed above, these childlessness separation procedures will at worst provide tentative approximations of the percentages of women in the various categories of childlessness. We now apply the behavioral approach to data from the 2006-10 National Survey of Family Growth (NSFG) for NonHispanic (NH) White women, NonHispanic $(\mathrm{NH})$ Black women, and Hispanic women. Our earlier research (Poston et al., 1983) indicates that although the cognitive and behavioral approaches are conceptually different, they lead to somewhat similar empirical results. For this reason we only employ one of the separation strategies in this article.

We begin with the 11'557 women in the 2006-10 NSFG (see Figure 1). Of these, 6'299 are NH Whites, 2'723 are Hispanics, and 2'535 are non-Hispanic Blacks. We focus first on the NH White women.

From the sample of 6'299 NH White women, we exclude those 232 women who were pregnant at the time the interviews were conducted because of the difficulty in classifying them accurately. As we have already noted, they are neither childless nor childed. Remaining for analysis are 6'067 NH White women who are not currently pregnant. Of these, 3'147 were childless, and 2'920 reported having one or more live births. We are able now to complete the identification of the «childed» category; 2'920 women are childed.

Next, we separate out from the 3'147 childless women the temporary childless women by examining responses to the NSFG question, «Do you want a(nother) baby some time?»; 2'414 women intend to have one or 
more children, but as of the date of the NSFG interview, they are childless. We thus classify these 2'414 women as «temporarily childless».

FIGURE 1 Decision tree: Women categorized by type of childlessness, using the behavorial approach: NH White woman, 2006-2010

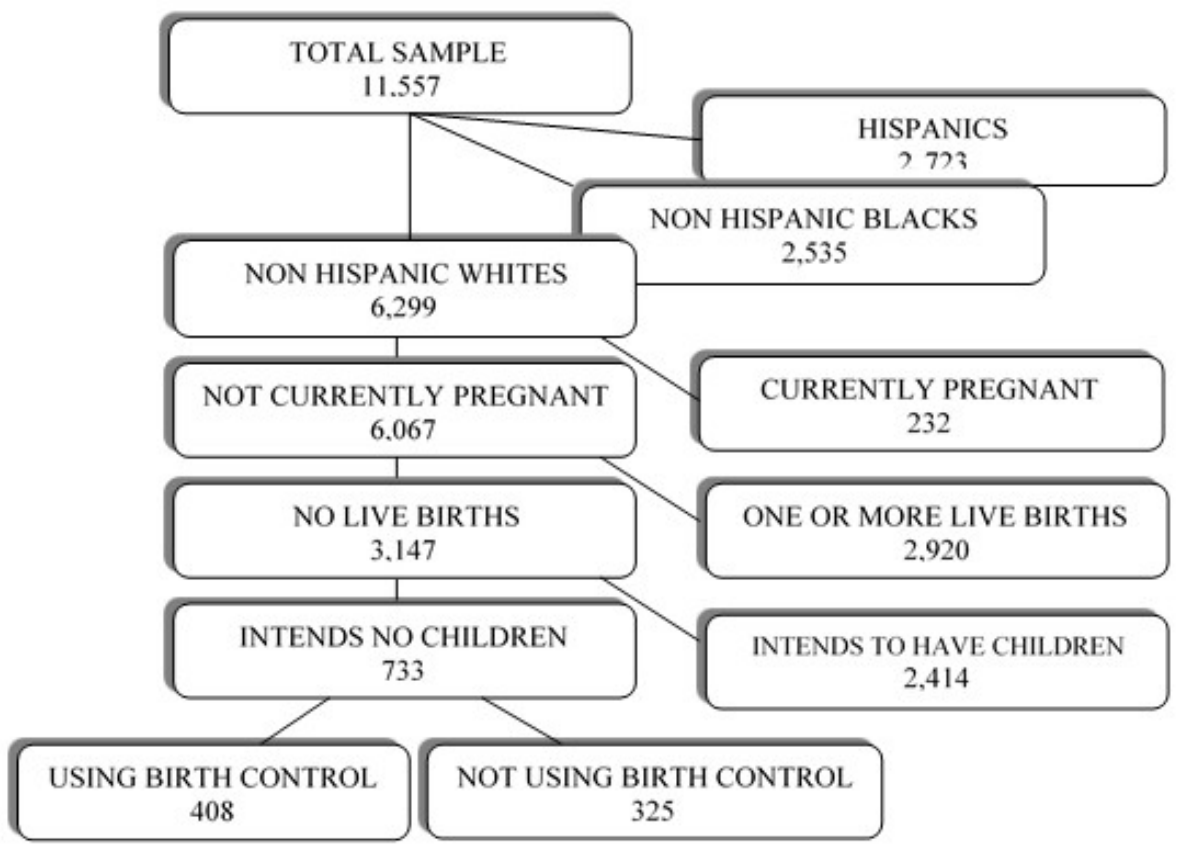

Remaining for analysis are $733 \mathrm{NH}$ White women who are childless and who do not intend to have any children in the future. Our task now is to separate these 733 childless women into voluntarily and involuntarily childless groups using the behavioral approach.

We refer to the questionnaire item concerning birth control. The category of women who are using birth control includes women who are contracepting and women who are not contracepting but who themselves or their partners have been contraceptively sterilized. There are 408 women who are using birth control as just defined; we identify this group of women as voluntarily childless. 
TABLE 2 Frequency distributions of women 20-44 years of age by categories of childlessness, and childed; NonHispanic White, NonHispanic Black, and Hispanic women - United States, 2006-2010

Childlessness category and childed

\begin{tabular}{|l|r|r|r|r|r|r|r|r|r|r|}
\hline Race/Hispanic & \multicolumn{2}{c}{$\begin{array}{c}\text { Voluntarily } \\
\text { chidless }\end{array}$} & \multicolumn{1}{|c|}{ Involuntarily } & \multicolumn{2}{c|}{$\begin{array}{c}\text { Temporarily } \\
\text { childless }\end{array}$} & \multicolumn{2}{c|}{ Childed } & \multicolumn{2}{c|}{ Total } \\
\hline NonHispanic White & 408 & $6.7 \%$ & 325 & $5.4 \%$ & $2^{\prime} 414$ & $39.8 \%$ & $2^{\prime} 920$ & $48.1 \%$ & $6^{\prime} 067$ & $100 \%$ \\
\hline NonHispanic Black & 81 & $3.4 \%$ & 109 & $4.5 \%$ & 740 & $30.6 \%$ & $1^{\prime} 486$ & $61.5 \%$ & $2^{\prime} 416$ & $100 \%$ \\
\hline Hispanic & 54 & $2.1 \%$ & 80 & $3.1 \%$ & 827 & $32.0 \%$ & $1^{\prime} 620$ & $62.8 \%$ & $2^{\prime} 581$ & $100 \%$ \\
\hline
\end{tabular}

FigURE 2 Decision tree: Women categorized by type of childlessness, using the behavorial approach: NH Black woman, 2006-2010

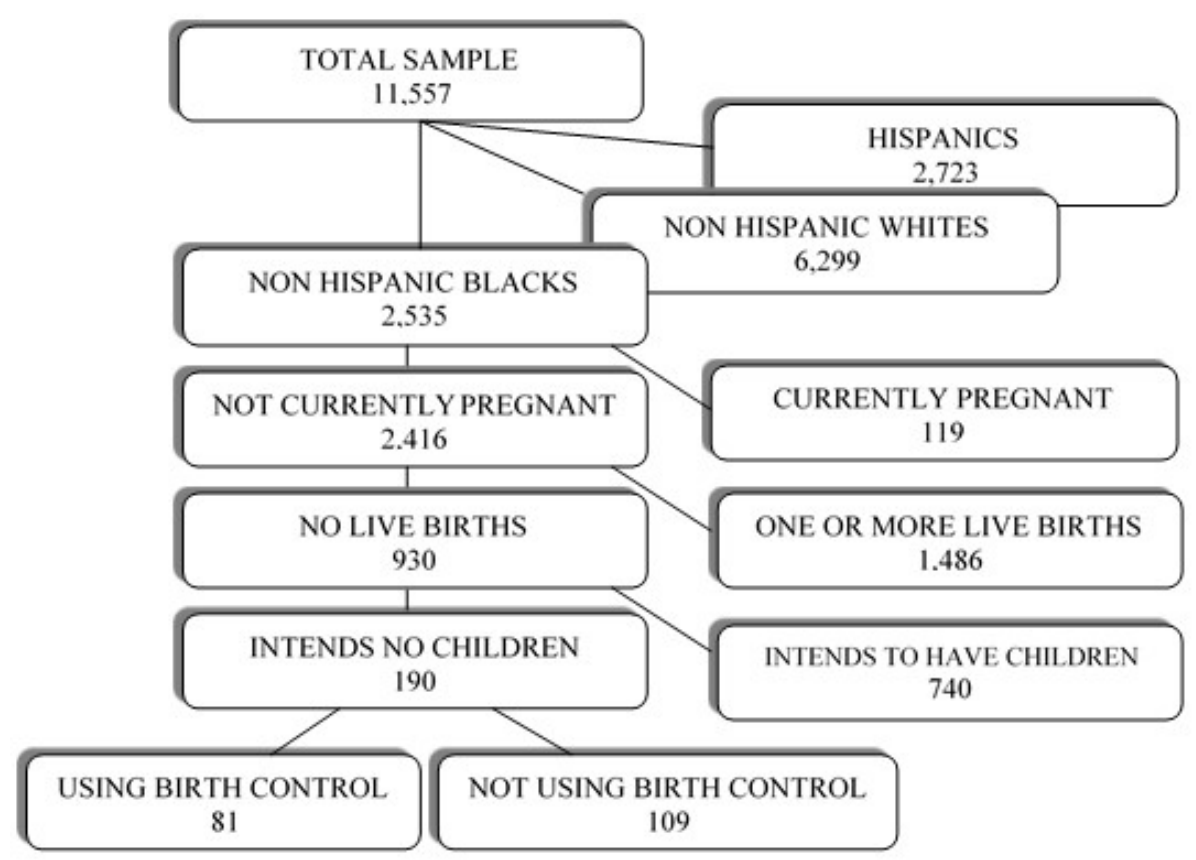

The remaining 325 women who are not using birth control are identified as involuntarily childless. These 325 women include 230 who are currently not contracepting, 92 who have never contracepted, and 3 who are noncontraceptively sterilized or have noncontraceptively sterilized partners. 
FiguRE 3 Decision tree: Women categorized by type of childlessness, using the behavorial approach: Hispanic woman, 2006-2010

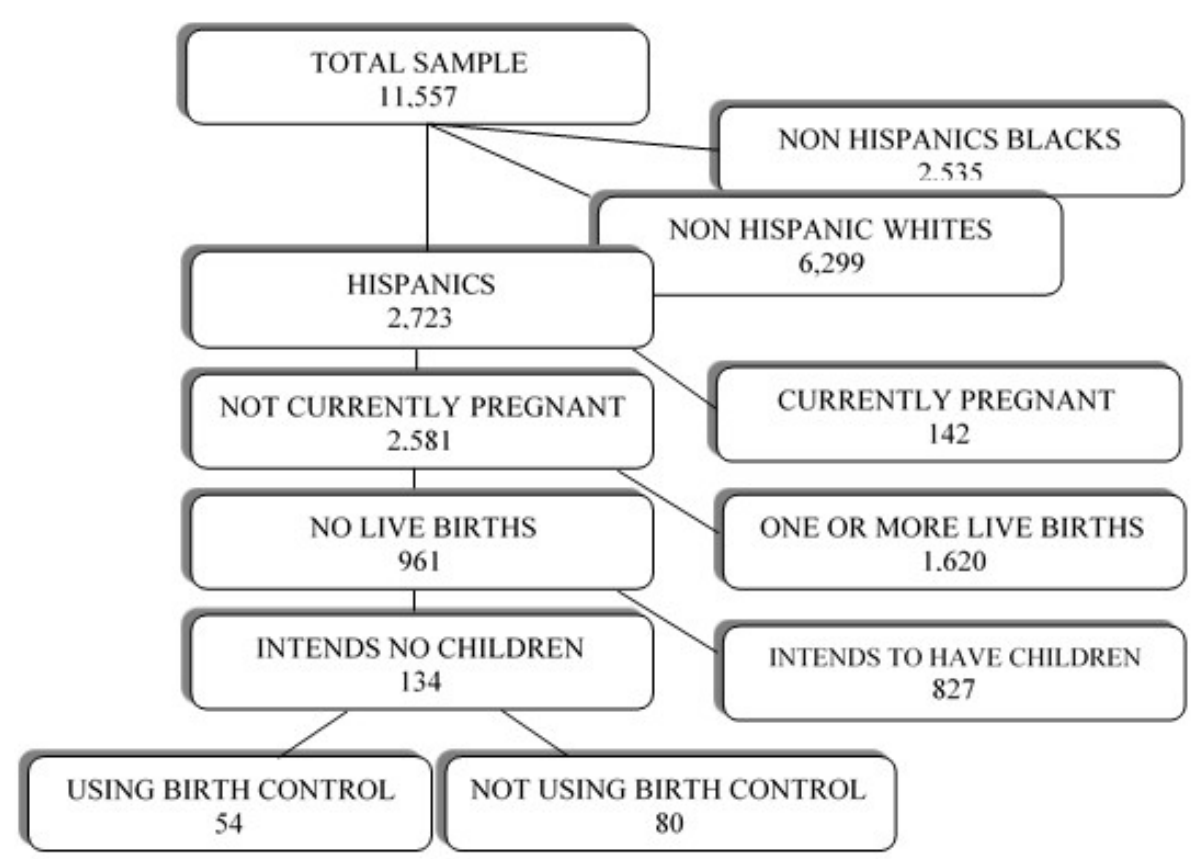

This behavioral categorization strategy leaves us with 408 women whom we have identified as voluntarily childless, 325 women whom we have identified as involuntarily childless, 2'414 temporarily childless, and 2'920 childed, i.e., women who have had one or more live births.

We summarize these categorizations in Table 2 . Almost half $(48.1 \%)$ of all the NH White women have one or more children, leaving just over half (51.9\%) who are childless. Of these, $39.8 \%$ are temporarily childless, $6.7 \%$ are voluntarily childless, and $5.4 \%$ are involuntarily childless.

We have implemented the same behavioral approach as described above for NH Black women and for Hispanic women. The step-by-step calculations are shown in Figures 2 and 3. The results are summarized in Table 2 (above). Percentage wise, there are many more voluntarily childless women among NH Whites than among the other two groups. There are more than three times as many voluntarily childless NH White women compared to Hispanic women, and just about twice as many compared to Black women. And there are more temporarily childless NH Whites than Blacks or Hispanics. In all three groups the percentages of involuntarily 
childless are low, from 3 to $5 \%$. We turn next to multivariate analyses of factors associated with a woman's type of childlessness.

\section{Statistical models}

We use four independent variables, namely, age of the respondent measured in years; the respondent's education measured as three dummy variables, 9 years of education or less, 10-12 years, and 13+ years (the 9 years or less category is used as the reference group); a dummy variable indicating whether or not the woman is never-married, and a dummy variable indicating if she is separated (for both dummy variables, yes is scored as 1 , no as 0 ).

We undertake three multivariate analyses of childlessness, one each among NH White women, NH Black women, and Hispanic women. Specifically, we use multinomial logistic regression because the dependent variable is both categorical and unordered (Hanushek et al., 1977). The dependent variable is the four category variable of temporarily childless, voluntarily childless, involuntarily childless, and childed, a categorization based on the behavioral approach (as summarized in Table 2). The childed category is the reference category.

Following the literature, we expect education to be positively related to the probability of being voluntarily childless and negatively related or not related, to the probability of being involuntarily childless. Regarding marital status, we expect never married women compared to married women to be more likely to be childless. Age should be negatively associated with all three forms of childlessness; the older the women, on average, the less likely she will be childless; this negative relationship should be the strongest with respect to temporary childlessness.

We first need to attend to an important methodological issue. We noted earlier that the 2006-10 NSFG consists of data for women and men, aged 15-44, in households in the United States. Mosher (2010, p. 33) has written that this sample:

\footnotetext{
«is a nationally representative multistage area probability sample drawn from 85 areas across the country... Persons were selected for the NSFG in five major steps: Large areas (counties and cities) were chosen first. Within each large area or 'Primary Sampling Unit,' groups of adjacent blocks ... were chosen at random. Within segments, addresses were listed and some addresses were selected at random. The selected addresses were visited in person ... (If it was determined that a person 15-44 lived at the address, then) ... one person was chosen at random for the interview and was offered a chance to participate».
} 
Since the 2006-10 NSFG is based on multistage probability sampling, one cannot make inferences with the data to the larger population of U.S. adults from which the sample was drawn without first taking into account its complex sampling design. Otherwise, the data will be treated by the statistical software as based on a simple random sample. This will tend:

\begin{abstract}
«to understate the true extent of sampling error in the data... (because) when observations are clustered (i.e., drawn from a few selected sampling points as is the case with the 2006-10 NSFG), for many variables the within-cluster variance tends to be smaller than the variance across the population as a whole. This in turn implies that the between-cluster variance, i.e., the variance of the cluster means, which gives the standard error for clustered samples, is inflated relative to the variance of the same variable computed from a simple random sample drawn from the same population. Reduced within-cluster variance, especially with respect to sociodemographic variables, is typical within the small areas that make up... (a) stage of multistage probability samples: areas of a few blocks tend to be more homogeneous with respect to education, age, race, and so on than the population of the entire country. The result is that when we use statistical procedures based on the assumption of simple random sampling, our computed standard errors typically are too small. What we need to do is to take account not only of the variance among individuals within a cluster, but of the variance between clusters» (Treiman, 2009, pp. 207-208).
\end{abstract}

Thus in the empirical analysis reported here, we use the «svy» suite of statistical sample adjustment methods available in the Stata 13 statistical package (StataCorp, 2014) that introduce survey adjustment estimators. We are thus able to adjust our analyses according to the various population and strata weights available in the 2006-10 NSFG.

\title{
Results
}

Table 3 reports the results from the maximum-likelihood multinomial logistic regression estimated for $\mathrm{NH}$ White women. The statistically significant F-test value is 68.56 and is easily large enough to reject the null hypothesis that all the multinomial logit coefficients are zero. The table also reports the multinomial logit coefficients reporting the log odds of a woman for each unit of the independent variable of being in one of the childlessness categories, relative to being childed.

We see that women in the high education category are more likely to be voluntarily and temporarily childless, relative to having children. The coefficients for the 13+ years of education category is 1'344 for voluntary childlessness and 1'853 for temporary childlessness. Let us interpret these coefficients via the odds ratio, $\Omega$. We thus exponentiate the coeffi- 
cient for voluntary childlessness, that is, $e^{1^{\prime} 344}=3^{\prime} 834$, and we exponentiate the coefficient for temporary childlessness, that is, $e^{1^{\prime} 853}=6^{\prime} 379$. These tell us that $\mathrm{NH}$ White women with $13+$ years of education have odds of being voluntarily childless versus being childed, i.e., having one or more children, that are 3.8 times greater than the odds of women with 9 years of less of education. And the odds of these highly educated White women being temporarily childless, versus being childed, are 6.4 times greater than those of lowly educated White women. Education is a powerful predictor of voluntary and temporary childlessness. Education does not have a statistically significant influence on the odds of White women being involuntarily childless.

TABLE 3 Multinomial logistic regression results of women being childless versus childed on selected social and demographic factors: 6'067 NonHispanic White women, 20-44 years of age - United States, 2006-2010

Childlessness category (versus childed)

\begin{tabular}{|c|c|c|c|}
\hline \multirow[t]{2}{*}{ Independent variables } & $\begin{array}{l}\text { Voluntarily } \\
\text { childless }\end{array}$ & $\begin{array}{l}\text { Involuntarily } \\
\text { childless }\end{array}$ & $\begin{array}{c}\text { Temporarily } \\
\text { childless }\end{array}$ \\
\hline & \multicolumn{3}{|c|}{ Behavioral separation method } \\
\hline Age (years) & -0.021 & -0.016 & $-0.234^{*}$ \\
\hline \multicolumn{4}{|l|}{ Education } \\
\hline 9 years or less & (ref) & (ref) & (ref) \\
\hline $10-12$ years & 0.696 & -0.273 & 0.300 \\
\hline $13+$ years & $1.344 *$ & 0.114 & $1.853^{*}$ \\
\hline Never married (yes $=1$ ) & $1.562^{*}$ & $2.497^{*}$ & $1.560^{*}$ \\
\hline Separated/divorced (yes $=1$ ) & 0.369 & $0.965^{*}$ & -0.168 \\
\hline Intercept & $-3.140 *$ & $-3.065^{*}$ & $4.339 *$ \\
\hline $\mathrm{N}$ & 408 & 325 & 2,414 \\
\hline F-test & \multicolumn{2}{|c|}{$68.56^{*}$} & \\
\hline
\end{tabular}

${ }^{*} p<.05$. The reference group is childed women $\left(N=2^{\prime} 920\right)$.

The dummy variable indicating whether the woman is never married is positive and significant for all three categories of childless women. Specifically, compared to married women, never married White women are 4.8 times more likely to be voluntarily childless relative to having children, that is, $e^{1^{\prime} 562}=4^{\prime} 763$. As expected, this marital status variable has by far the strongest effects of all the independent variables. It is best used as a control variable rather than as an explanatory variable, and this is especially the case for NH White women.

Age has a statistically significant negative effect only on being temporarily childless. This confirms the earlier point that the temporarily childless 
tend to be younger and, by definition, cannot remain temporarily childless through their reproductive years. Age is not a significant predictor of being voluntarily or involuntarily childless, but its coefficients are negatively signed, as predicted.

TABLE 4 Multinomial logistic regression results of women being childless versus childed on selected social and demographic factors: 2'416 NonHispanic Black women, 20-44 years of age - United States, 2006-2010

\begin{tabular}{|c|c|c|c|}
\hline \multirow[t]{2}{*}{ Independent variables } & $\begin{array}{c}\text { Voluntarily } \\
\text { childless }\end{array}$ & $\begin{array}{l}\text { Involuntarily } \\
\text { childless }\end{array}$ & $\begin{array}{c}\text { Temporarily } \\
\text { childless }\end{array}$ \\
\hline & \multicolumn{3}{|c|}{ Behavioral separation method } \\
\hline Age (years) & -0.014 & $-0.072^{*}$ & $-0.164^{*}$ \\
\hline \multicolumn{4}{|l|}{ Education } \\
\hline 9 years or less & (ref) & (ref) & (ref) \\
\hline $10-12$ years & 1.067 & -0.722 & $-0.564 *$ \\
\hline $13+$ years & $1.801^{*}$ & -0.225 & $0.533^{*}$ \\
\hline Never married (yes $=1$ ) & $1.302 *$ & $2.199 *$ & $0.833^{*}$ \\
\hline Separated/divorced (yes $=1$ ) & 0.957 & 1.294 & -0.238 \\
\hline Intercept & $-4.740^{*}$ & $-1.814^{*}$ & $3.236^{*}$ \\
\hline $\mathrm{N}$ & 81 & 109 & 740 \\
\hline F-test & \multicolumn{2}{|c|}{$18.16^{*}$} & \\
\hline
\end{tabular}

Table 4 shows the results from the maximum-likelihood multinomial logistic regression equation that we estimated for NH Black women. As was the situation for $\mathrm{NH}$ White women, the coefficients reporting the effects of $13+$ years of education on women being in the two categories of voluntary childlessness and temporary childlessness are positive and statistically significant. The high education variable does not display a statistically significant coefficient with regard to women being in the involuntary childlessness category, which is the same finding shown above for NH White women. Also, never married Black women are more likely than married Black women to be childless (all three categories of childlessness) versus having children. This was also the situation for NH White women (Table 3). Similarly, age has a strong and negative effect on the likelihood of Black women being temporarily childless. The results for the NH Black women (Table 4) are very similar to those for NH White women (Table 3).

Table 5 shows the multinomial logistic regression results for Hispanic women. As was the situation for the NH White women and the NH Black 
women, the coefficients reporting the effects of $13+$ years of education for women being in the two categories of voluntary childlessness and temporary childlessness are positive and statistically significant. Highly educated Hispanic women are 4 times more likely to be voluntarily childless relative to having children, that is, $e^{1^{\prime} 376}=3.96$, and more than 12 times more likely to be temporarily childless, compared to women with children. With regard to the effects of education on the likelihood of being involuntarily childless, there is no significant relationship for Hispanic women with 10-12 years of education of being more likely than Hispanic women with 9 or less years of education of being involuntarily childless.

TABLE 5 Multinomial logistic regression results of women being childless versus childed on selected social and demographic factors: 2'581 Hispanic women, 20-44 years of age United States, 2006-2010

Childlessness category (versus childed)

\begin{tabular}{|c|c|c|c|}
\hline \multirow[t]{2}{*}{ Independent variables } & $\begin{array}{l}\text { Voluntarily } \\
\text { childless }\end{array}$ & $\begin{array}{l}\text { Involuntarily } \\
\text { childless }\end{array}$ & $\begin{array}{l}\text { Temporarily } \\
\text { childless }\end{array}$ \\
\hline & \multicolumn{3}{|c|}{ Behavioral separation method } \\
\hline Age (years) & $-0.068^{*}$ & $-0.092^{*}$ & $-0.245^{*}$ \\
\hline \multicolumn{4}{|l|}{ Education } \\
\hline 9 years or less & (ref) & (ref) & (ref) \\
\hline $10-12$ years & -0.314 & 0.636 & $0.441^{*}$ \\
\hline $13+$ years & $1.376^{*}$ & $0.333^{*}$ & $2.535^{*}$ \\
\hline Never married (yes $=1$ ) & $1.687^{*}$ & $2.527^{*}$ & $1.806 *$ \\
\hline Separated/divorced (yes $=1$ ) & 1.014 & 0.998 & 0.157 \\
\hline Intercept & $-2.833^{*}$ & $-2.841^{*}$ & $3.477^{*}$ \\
\hline $\mathrm{N}$ & 54 & 80 & 827 \\
\hline F-test & \multicolumn{2}{|c|}{$28.74^{*}$} & \\
\hline
\end{tabular}

${ }^{*} p<.05$. The reference group is childed women $\left(N=1^{\prime} 620\right)$.

But there is a positive and significant relationship for Hispanic women with 13+ years of education being involuntarily childless. This is a finding that was not expected. We anticipated that for Hispanic women the high education variable would either not be related, or would be negatively related, to the likelihood of being involuntarily childless, as was the case for NH White and NH Black women. The fact that Hispanic women with high levels of education are more likely to be involuntarily childless rather than having children, compared to Hispanic women with low levels of education, may be due in part to the low percentage of Hispanic women being in the high education category (less than one-third and much lower 
than that for NH White and NH Black women), and the very small number of Hispanic women being involuntarily childless $(\mathrm{N}=80)$.

Another reason lies in the fact that demographically the Hispanic population in the United States behaves in many unexpected and not well understood ways. Both Hispanics and NH Blacks are socioeconomically disadvantaged populations. Accordingly, one would expect their demographic outcomes to be fairly similar. But they are not. Hispanics live several years longer than Blacks (and Whites), a phenomenon known as the Hispanic epidemiological paradox (Markides et al., 1986). This paradox has also been examined with regard to causes of death (Dominguez et al., 2015), and with regard to the incidence of sexually transmitted infections (Obregon, 2015). In both examinations, Hispanics do not behave in the same way as Blacks. Moreover, Hispanics, compared to Blacks, have much lower percentages of births to unwed mothers; and they have much higher fertility rates than Blacks (Poston et al., 2016). Also, Hispanics in segregated neighborhoods have lower crime rates than Blacks living in segregated neighborhoods, a phenomenon known as the Hispanic criminological paradox (Romero, 2014). In all these comparisons, Hispanics differ from Blacks, and demographers do not agree why. The fact that highly educated Hispanic women, compared to those with few years of education, are more likely to be involuntarily childless than to have children, seems to be yet another of many demographic outcomes where Hispanics differ from Black (and White) women. Demographers need to pay more attention to this unexpected behavior in their future analyses of childlessness.

Overall, however, the multinomial regression results reported in Tables 4 and 5 for minority women are more similar than they are different when compared to those for the majority White women as reported in Table 3. Thus despite the fact that the rates of fertility for the minority women, especially for the Hispanic women, are higher than for the White women, the effects of the various independent variables on the categories of childlessness are pretty much the same.

\section{Conclusion}

In this article we first examined overall trends from 1910 to 2010 in the levels of childlessness among ever-married White, Black and Hispanic women. For the most part, our analyses over the 100 year period showed 
higher levels of age-specific rates of childlessness for the more recent cohorts compared with the earlier cohorts. The levels of completed childlessness for the cohorts about to finish their childbearing will likely be around $15-17 \%$ for all ever-married women, and perhaps as high as $20 \%$ for all women. However, the decennial census and Current Population Survey data we used in the analysis of childlessness trends did not permit us to distinguish among women who are voluntarily, involuntarily, and temporarily childless. These are important distinctions because, among other considerations, some of their causes are not necessarily the same.

We then drew on data from the 2006-10 National Survey of Family Growth to determine for ever-married women three categories of childlessness (voluntary, involuntary, and temporary), plus a fourth category representing women with children. We used a behavioral approach to separate the women into the categories; we did this separately for NonHispanic White women, Non-Hispanic Black women and Hispanic women.

For all three groups of women, we then set forth a few hypotheses about the characteristics of childless women, and tested these hypotheses with results from multinomial logistic regressions. We found that an important predictor of whether a woman was childless (in two of the three categories) versus having children was her level of education. For the most part, women with 13+ years of schooling, compared to those with 9 or fewer years, were more likely to be voluntarily or temporarily childless, as opposed to being childed. Also, never married women were shown to be much more likely than currently married women to be childless (in any of the three categories) than to have children.

Finally, there is an interesting empirical inconsistency in our above analyses, which deserves mentioning. The decennial census and Current Population Survey data reported in this article, and elsewhere, show increases since the 1970s in the levels of permanent childlessness of evermarried women in the United States. And we saw similar increases in our national data; for the most part, the younger the cohort, the higher their completed rate of childlessness. As we just noted in an earlier paragraph, it appears that 15 to $18 \%$, perhaps as high as $20 \%$, of contemporary cohorts of women will end up being childless by the time they are 45 years old. However, the survey data from the 2006-10 NSFG on childlessness show considerably lower levels of voluntary and involuntary childlessness among older ever-married women, and higher levels of temporary childlessness. To illustrate, the percentages of voluntary, involuntary and temporary childlessness for 20-44 year old $\mathrm{NH}$ white women are $6.7 \%$, $5.4 \%$, and $39.8 \%$, respectively; and the percentages are slightly lower for 
$\mathrm{NH}$ black women and hor Hispanic women. Therefore, there seems to be a lack of correspondence between these two sources.

This difference may be understandable given the apparent hesitation, even these days, for some women to admit specifically that they are permanently childless. Instead, the easy response, from a normative point of view, is to note that their childlessness is temporary, which may well be a truthful response for many women.

However, research conducted since the 1970s has continually shown that whereas many of the temporarily childless women end up eventually having children, there are also many of them who «continue to postpone having their first child, maintaining the advantages of their childless lifestyles» (Poston et al., 1983, p. 295). The work of Veevers (1973) is especially applicable in this regard. In her studies of voluntarily childless wives, she showed that two-thirds of the childless women in her samples did not decide on childlessness prior to marriage, but «remained childless as a result of decisions to postpone having children until some future time, a future which never came» (1973, p. 359).

This would suggest that about one-half of the temporarily childless women in the 2006-10 NSFG sample could well end up being permanently childless. This sort of outcome would be one way of addressing the empirical inconsistency regarding levels of childlessness that are reflected in the data. The National Center for Health Statistics could address this inconsistency head-on by including questions in future fertility surveys that probe in greater detail the fertility intentions and dispositions of the childless respondents.

\section{References}

Abma J. C., Chandra A., Mosher W. D., Peterson L. S., Piccinino L. J. (1997), «Fertility, Family Planning, and Women's Health: New Data from the 1995 National Survey of Family Growth», Vital and Health Statistics, 23 (19), pp. 1-114.

Abma J. C., MARTinez G. M. (2006), «Childlessness among Older Women in the United States: Trends and Profiles", Journal of Marriage and Family, 68, pp. 1'045-1'056.

Abma J. C., Peterson L. S. (1995), «Voluntary Childlessness among U.S. Women: Recent Trends and Determinants», Paper presented at Annual Meeting of the Population Association of America, San Francisco, CA, April 6-8.

Baudin T., DE LA Croix D., GobBi P. E. (2015), «Fertility and Childlessness in the United States», American Economic Review, 105 (6), pp. 1'852-1'882. 
BLAKE J. (1974), «Can We Believe the Recent Data on Birth Expectations in the United States?», Demography, 11, pp. 25-44, http://dx.doi.org/10.2307/2060697.

Debest C., Mazuy M., The Fecond Survey Team (2014), "Childlessness: A Life Choice that Goes Against the Norm», Population and Societies, 508, February, pp. 1-4.

Dominguez K., Penman-Aguilar A., Chang M.-H., Moonesinghe R., Castellanos T., Rodriguez-Lainz A., SCHieber R. (2015), "Leading Causes of Death, Prevalence of Diseases and Risk Factors, and Use of Health Services among Hispanics in the United States, 2009-2013», Morbidity and Mortality Weekly Report, 64, pp. 469-478.

Downs B. (2003), "Fertility of American Women: June 2002», Current Population Reports, Washington, DC, U.S. Census Bureau, pp. 20-548.

Dykstra P. A. (2009), «Childless Old Age», P. Uhlenberg (ed), International Handbook of Population Aging, New York, Springer Publishers, pp. 671-690, http://dx.doi.org/ 10.1007/978-1-4020-8356-3_30.

GRIFFITH J. (1973), "Social Pressures on Family Size Intentions», Family Planning Perspectives, 5, pp. 237-242, http://dx.doi.org/10.2307/2133976.

Hanushek E., Jackson J. E. (1977), Statistical Methods for Social Sciences, New York, Academic Press, http://dx.doi.org/10.1007/978-1-4615-7151-3_14.

HOUSEKNECHT S. K. (1987), "Voluntary Childlessness», M. B. SUSSMAN, S. K. STEINMETZ (eds), Handbook of Marriage and the Family, New York, Plenum Press, pp. 369-395.

Koropecky-Cox T. K., Pendell G. (2007), «Attitudes about Childlessness in the United States: Correlates of Positive, Neutral, and Negative Responses» Journal of Family Issues, 28, pp. 1'054-1'082.

Letherby G. (2002), "Childless and Bereft?: Stereotypes and Realities in Relation to 'Voluntary' and 'Involuntary' Childlessness and Womanhood», Sociological Inquiry, 72, pp. 7-20, http://dx.doi.org/10.1111/1475-682X.00003.

MARKIDES K. S., COREIL J. (1986), «The Health of Hispanics in the Southwestern United States: An Epidemiologic Paradox», Public Health Reports, 101, pp. 253-265.

McFalls J. A. (1979a), Psychopathology and Subfecundity, New York, Academic Press.

McFalls J. A. (1979b), «Frustrated Fertility: A Population Paradox», Population Bulletin, 34 (2), pp. 3-43.

Merton R. K. (1957), Social Theory and Social Structure, Glencoe, Illinois, The Free Press.

Morgan S. P. (1991), "Late Nineteenth- and Early Twentieth-Century Childlessness», American Journal of Sociology, 97, pp. 779-807, http://dx.doi.org/10.1086/229820.

Morgan S. P., Chen R. (1992), "Predicting Childlessness for Recent Cohorts of American Women", International Journal of Forecasting, 8, pp. 477-493, http://dx. doi.org/10.1016/0169-2070(92)90059-I. 
Mosher W. D. (2010), "Use of Contraception in the United States: 1982-2008», Vital and Health Statistics, National Center for Health Statistics, 23 (29).

Obregon M. (2015), Extending the Latino Paradox: Comparative Findings of STIS among Birth Giving Mexican Origin, Black and White Women, Ph.D. diss., Texas A\&M University, College Station.

PARK K. (2005), «Choosing Childlessness: Weber's Typology of Action and Motives of the Voluntarily Childless», Sociological Inquiry, 75, pp. 372-402, http://dx.doi.org/ 10.1111/j.1475-682X.2005.00127.x.

Poston D. L. JR. (1974), "Income and Childlessness in the United States: Is the Relationship Always Inverse?», Social Biology, 21, pp. 296-307, http://dx.doi.org/10. 1080/19485565.1974.9988124.

Poston D. L. JR. (1976), «Characteristics of Voluntarily and Involuntarily Childless Wives», Social Biology, 23, pp. 198-209, http://dx.doi.org/10.1080/19485565.1976. 9988231.

Poston D. L. JR. (1990), «Voluntary and Involuntary Childlessness among Catholic and non-Catholic Women: Are the Patterns Converging?», Social Biology, 37, pp. 251265, http://dx.doi.org/10.1080/19485565.1990.9988764.

Poston D. L. JR., Bouvier L. F. (2016), Population and Society: An Introduction to Demography, 2nd edition, New York, NY, Cambridge University Press.

Poston D. L. JR., Gotard E. (1977), "Trends in Childlessness in the United States, 1910-1975», Social Biology, 24, pp. 212-234, http://dx.doi.org/10.1080/19485565. 1977.9988284.

Poston D. L. JR., KRAmer K. B. (1983), «Voluntary and Involuntary Childlessness in the United States, 1955-1973», Social Biology, 30, pp. 290-306, http://dx.doi.org/10. 1080/19485565.1983.9988543.

Poston D. L. JR., Kramer K.B., Trent K., Yu M.-Y. (1983), «Estimating Voluntary and Involuntary Childlessness in the Developing Countries of the World", Journal of Biosocial Science, 15, pp. 441-452, http://dx.doi.org/10.1017/S0021932000020897.

Poston D. L. JR., Trent K. (1982), «International Variability in Childlessness: A Descriptive and Analytical Study", Journal of Family Issues, 3, pp. 473-491, http://dx. doi.org/10.1177/019251382003004004.

PrICE D. O. (1968), «Educational Differentials between Negroes and Whites in the South», Demography, 5, pp. 23-33, http://dx.doi.org/10.1007/BF03208558.

PrICE D. O. (1974), «Constructing Cohort Data from Discrepant Age Intervals and Irregular Reporting Periods», Social Science Quarterly, 55, pp. 167-174.

Rindfuss R. R., Morgan S. P., SWicegood G. (1988), First Births in America: Changes in the Timing of Parenthood. Berkeley, CA, University of California Press.

Romero F. (2014), The Residential Segregation of Latino Immigrants in the U.S.: Exposure to Crime and the Effects of Place of Destination, Ph.D. diss., Texas A\&M University, College Station. 
Rowland D. T. (1998a), "Consequences of Childlessness in Later Life», Australian Journal on Aging, 17, pp. 24-28, http://dx.doi.org/10.1111/j.1741-6612.1998. tb00220.x.

Rowland D. T. (1998b), "The Prevalence of Childlessness in Older Cohorts of Women», Australian Journal on Aging, 17, pp. 18-23, http://dx.doi.org/10.1111/j. 1741-6612.1998.tb00219.x.

RowLAND D. T. (2007), "Historical Trends in Childlessness», Journal of family Issues, 28, pp. 1'311-1'337.

StataCorp (2014), Stata Survey Data Reference Manual, Release 13, College Station, TX.

Toulemon L. (1996), "Very Few Couples Remain Voluntarily Childless», Population: An English Selection, 8, pp. 1-27.

Treiman D. J. (2009), Quantitative Data Analysis: Doing Social Research to Test Ideas, San Francisco, CA, Jossey-Bass.

U.S. Bureau of the Census (1943), U.S. Census of Population: 1940. Differential Fertility: 1940 and 1910. Fertility for States and Large Cities, Washington D.C., Government Printing Office.

U.S. Bureau of the Census (1955), U.S. Census of Population: 1950. Vol. IV, Special Reports. Part 5, Chapter C, Fertility, Washington D.C., Government Printing Office.

U.S. Bureau of the Census (1964), U.S. Census of Population: 1960. Subject Reports, Women by Number of Children Ever Born, Final Report PC (2) - 3A, Washington D.C., Government Printing Office.

U.S. Bureau of the Census (1969), Current Population Reports, Series P-20, No. 186. Marriage, Fertility and Childspacing: June, 1965, Washington D.C., Government Printing Office.

U.S. Bureau of the Census (1973), U.S. Census of Population: 1970. Subject Reports, Women by Number of Children Ever Born, Final Report PC (2) - 3A, Washington D.C., Government Printing Office.

U.S. Bureau of the Census (1976), Current Population Reports, Series P-20, No. 301. Fertility of American Women: June, 1975, Washington D.C., Government Printing Office.

U.S. Bureau of the Census (1982), Current Population Reports, Series P-20, No. 375. Fertility of American Women: June, 1980, Washington D.C., Government Printing Office.

U.S. Bureau of the Census (1986), Current Population Reports, Series P-20, No. 406. Fertility of American Women: June, 1985, Washington D.C., Government Printing Office.

U.S. Bureau of the Census (1991), Current Population Reports, Series P-20, No. 454. Fertility of American Women: June, 1990, Washington D.C., Government Printing Office. 
U.S. Bureau of the Census (1997), Current Population Reports, Series P-20, No. 499. Fertility of American Women: June, 1995 (Update), Washington D.C., Government Printing Office.

U.S. Bureau of the Census (2010), Current Population Reports, Series P-20, No. 563. Fertility of American Women: 2008, Washington D.C., Government Printing Office.

U.S. Bureau of the Census (2011), Current Population Survey Data on Fertility, www.census.gov/hhes/fertility/data/cps/ (accessed July 17, 2013).

Veevers J. E. (1972), «Factors in the Incidence of Childlessness in Canada: An Analysis of Census Data», Social Biology, 19, pp. 266-274, http://dx.doi.org/10.1080/ 19485565.1972.9987994.

Veevers J. E. (1973), "Voluntarily Childless Wives: An Exploratory Study», Sociology and Social Research, 57, pp. 356-366.

Whelpton P. K., CAmpbell A. A., Patterson J. E. (1966), Fertility and Family Planning in the United States, Princeton, Princeton University Press, http://dx.doi.org/10. $1515 / 9781400877447$.

WILKIE J. R. (1984), "Involuntary Childlessness in the United States», Zeitschrift fur Bevolkerungswissenschaft, 10, pp. 37-52. 